\title{
Prohibition Debate in Washington County, 1890-1894: Smith Wildman Brookhart's Introduction to Politics
}

\author{
George W. McDaniel
}

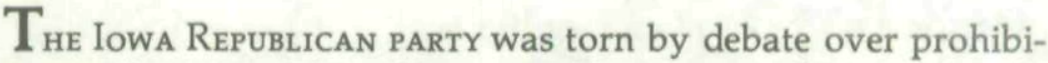
tion in the 1890s. The split occurred between traditional Republicans who favored a hard-line dry position for their party and a more moderate faction who hoped to recoup votes recently lost to wet Democrats by adopting a compromise position. Washington County, Iowa in the early 1890 s exemplified this party factionalism. The two Republican newspapers took opposing stances and augmented the debate. Out of this controversy the elective career of long-time Iowa politician Smith Wildman Brookhart was launched.

Until the 1960s Iowa had been considered a solid Republican state. In Congress between 1847 and 1953 there were $120 \mathrm{Re}$ publicans, 39 Democrats, and seven miscellaneous party representatives. ${ }^{1}$ Between the Civil War and the New Deal all governors except one were Republicans. The one exception to the overwhelming Republican domination of the statehouse occurred from 1889 to 1893 during Democrat Horace Boies's terms

${ }^{1}$ Mildred Throne, "Iowans in Congress, 1847-1953," Iowa Journal of History 51 (October 1953): 329-368. 
as governor. Boies's victory, however, cannot be thought a fluke. As Richard Jensen has shown in The Winning of the Midwest, the Republicans brought defeat upon themselves. Prohibition was the issue which brought about Republican defeat. It was, according to Jensen, "the paramount state or local issue, year in, and year out, throughout most of the Midwest . . . in the 1880 's." 2

There were three positions on the liquor question after the Civil War and the position one took had nearly as much to do with one's religion as one's politics. The first position was total abstinence. These total drys came from a pietistic religious tradition which emphasized the association of salvation with individual behavior. The liquor question, for these drys, became a crusade to protect home and family from the ravages liquor wrought in society. As Jensen has shown, they were almost exclusively Republicans. The second group was the liturgical and unchurched wets. The liturgicals were, generally speaking, Catholics, Anglicans, Lutherans, or other "high church" orthodox groups. They were opposed to prohibition but not necessarily to some tax or regulation of liquor. For the most part these were Democrats. The final group was the moderates, "who, whatever their own drinking habits, viewed the question not in the stark tones of the wets and drys, but in the gray zone of matters of practical public policy." Many Republicans were in this group. ${ }^{3}$

As the 1889 election approached the Republican party was split into two factions: the moderates who were willing to allow for local option on the liquor question and the drys who were opposed to anything but total prohibition. The drys were the dominant faction. In 1882 they had succeeded in getting a prohibition amendment to the Iowa constitution passed, only to have the Supreme Court declare it illegal because of a technical fault. Undaunted, the Republican 1884 and 1886 legislatures passed prohibition laws and, as the decade passed, prohibitionism and Republicanism became inseparable. Consequently, the 1889 Republican state convention was packed with radical drys.

${ }^{2}$ Richard J. Jensen, The Winning of the Midwest: Social and Political Conflict, 1888-1896 (Chicago: University of Chicago Press, 1971), p. 70.

${ }^{3}$ Ibid., pp. 92-93. 
Joseph Hutchinson, an undistinguished politician, but a dry, emerged as the gubernatorial nominee. Hutchinson was unacceptable to the moderates so they were left with two choices: stay home or vote Democratic. In 1889 and 1891 the moderates took one of these options and Democrat Horace Boies was twice elected. As the 1893 gubernatorial election approached, the Republican problem was how to "shake the albatross of dry platforms" and regain the statehouse. ${ }^{4}$

Smith Wildman Brookhart first ran for office in Washington County during this conflict. The historiography on Brookhart is slight. ${ }^{5}$ The common opinion, however, is that he started in politics as an anti-railroad politician. While he was later principally known for his fight against railroad and big business monopolies, and still later as a crusader for farmers' interests, Brookhart's first involvement in elective politics revolved around another controversy of the late nineteenth centuryprohibition.

Smith Wildman Brookhart was born in 1869, the first of eleven children. His early education was in rural schools, and as the eldest son of a farm family he might have been expected to carry on the farming tradition. He chose, however, to continue his education. After finishing high school in Bloomfield, Iowa,

${ }^{4}$ Ibid., p. 115.

${ }^{5}$ The only full life biography is Ray S. Johnston's unpublished thesis, "Smith Wildman Brookhart: Iowa's Last Populist" (M.A. thesis, Iowa State Teachers' College, 1964). Johnston's work, however, has been superseded in part as more manuscript collections have become available. For example, my essay, "Over Here: The Mobilization of the Republican Service League to Defeat Smith Wildman Brookhart" (M.A. essay, University of Iowa, 1977), made use of the Hanford MacNider Papers at the Herbert Hoover Presidential Library. The use of these papers altered the standard opinion about the 1924 Senate election. Other works about Brookhart include: Jerry Alvin Neprash, The Brookhart Campaigns in Iowa, 1920-1926 (New York: AMS Press, 1968); Corwin D. Cornell, "Smith W. Brookhart and Agrarian Discontent in Iowa" (M.A. thesis, University of Iowa, 1949); Barry A. Russell, "The Changing Concept of Iowa Progressivism: Smith W. Brookhart vs. Albert B. Cummins, 1920-1926" (M.A. thesis, University of North Carolina, 1973); Cornelius Holland Bull III, "Smith Wildman Brookhart-Neither God nor Little Fish" (Senior thesis, Department of History, Princeton University, 1950); Reinhard H. Luthin, "Smith Brookhart of Iowa: Insurgent Agrarian Politician," Agricultural History 25 (October 1951): 187-189. 


\section{The Annals of Iowa}

he attended Southern Iowa Normal School, graduating from the scientific tract in 1889 . He supported himself for a time by teaching school while he read law with Dillon $\mathrm{H}$. Payne in Bloomfield and later with William M. Walker in Keosauqua. He was admitted to the bar in $1892 .{ }^{6}$

Brookhart was probably first introduced to politics while he was with Payne. Dillon Payne was the brother-in-law and former law partner of James B. Weaver. Like Weaver, Payne ran for election as a candidate on the "anti-fusion" (Greenback) ticket in 1880; Payne, however, was unsuccessful. There is no question that Brookhart knew Weaver at this time. "We knew him best," Brookhart later wrote, "when he was at the zenith of his career. . . . As a statesman he is a pioneer in many of the reforms that are now agitating the whole country and promising a revolution of political systems." ${ }^{17}$ However, Weaver's Populist ideas had little effect on Brookhart's early career. Many years later Brookhart frankly admitted that in those early days he was a "scoffer against those prophets of the progress of our country. As I look back over it now I see things with a different view." ${ }^{8}$

Brookhart became a Republican and was active in party affairs. In 1892 (at age 23) he took to the stump with John H. Gear, the former Republican governor of Iowa and two-term congressman, who was seeking to regain the first district seat he had lost two years before. ${ }^{9}$ It is not surprising that Brookhart became a Republican. The Republicans were by far the majority party in Iowa. But more important, drys were Republicans and Brookhart was a dry. All his life he was a teetotaler and a fanatic prohibitionist. While other politicians might treat a

\footnotetext{
${ }^{6}$ The biographical material about Smith Brookhart was taken from a number of sources: Biographical Directory of the American Congress, 1774-1949 (Washington, D.C.: Government Printing Office, 1950), p. 894; "Smith Wildman Brookhart," address to the State University of Iowa Political Science Club, February 1932, Congressional Record, 72d Cong., 1st sess., pp. 6236-6239; Dillon H. Payne, et al., eds., Pioneer History of Davis County, Iowa (Bloomfield, Iowa: Bloomfield Democrat, 1927), p. 211; Washington Press, 29 August 1894.

${ }^{7}$ Washington County Press, 15 February 1912 (hereafter cited as Press).

${ }^{8}$ Congressional Record, 67th Cong., 4th sess., p. 2129.

'Johnston, "Smith Wildman Brookhart," p. 4. I have been unable to verify Johnston's statement.
} 
supporter to bourbon and branch water, Brookhart's idea of treating a political supporter was to "take him up to his room and offer him a big red apple." ${ }^{10} \mathrm{He}$ was not attracted to the People's party, whose platform does not mention prohibition at a time when the question was a volatile issue in Iowa. Furthermore, the People's party was a third party. Throughout his life Brookhart refused to join any third party, regardless of how sympathetic he may have been with its views. The wet stance of the Democratic party definitely ruled out support from Brookhart.

O $_{\mathrm{N}}$ December 9, 1892 the Washington Gazette carried a small notice that "S. W. Brookhart, a bright young lawyer from Keosauqua, has formed a partnership with Jackson Roberts under the firm Roberts \& Brookhart." In 1890, Washington County, Iowa had a population of 18,468 ; the city of Washington had a population of $3,235 .{ }^{11}$ City and county were solidly Republican and bone dry. When Smith Brookhart arrived two weekly Republican newspapers were published: the Washington Press and the Washington Gazette.

The Press's editor and publisher was Howard A. Burrell who guided the newspaper to support the moderate Republican view on prohibition. The Gazette, run by D. H. Logan and Samuel Wakefield Neal during the 1890 s, supported the drys. At the beginning of the decade the moderate Press far outstripped the dry Gazette in circulation-1,416 to 850 . By 1899 the Press's circulation only rose to 1,550 while Logan and Neal had boosted the Gazette to $1,458 .{ }^{12}$

${ }^{10}$ Louis H. Cook, "Brookhart, Insurgent," North American Review 231 (February 1931): 183.

${ }^{11}$ Iowa Official Register, 1890 (Des Moines: G. M. Ragsdale, state printer, 1888), pp. 144-145.

${ }^{12}$ N. W. Ayer and Son's American Newspaper Annual, 1890 (Philadelphia: N. W. Ayer and Son, 1890), p. 228; Ibid., 1899, p. 268. For a brief history of newspapers in Washington see Hugh H. McCleery, Newspapers and Other Publications of Washington, Iowa: A Brief History (Washington: Washington Evening Journal, 1944). Washington also had a Democratic paper, the Washington Democrat, and a politically independent paper, the Daily Hustler (later the Evening Journal). 
Brookhart wasted no time in getting involved in Washington County Republican politics. He was elected chairman of the county convention in August 1893, and the Gazette reported, he "made a good speech, bristling with points." ${ }^{13} \mathrm{He}$ and thirteen others were selected as delegates to the state convention later the same month.

Previously (in March 1893), the Republican State Central Committee had met in Des Moines to plan the state convention. ${ }^{14}$ They hoped to present a platform, and especially a prohibition plank, that would unify the dry and moderate factions of the party. The committee had two problems. They recognized that the strong identification of prohibition with Republicanism was forcing the moderate Republicans to turn to the Democrats, yet they did not want to alienate the drys. Second, they had to face the fact that prohibition did not work. Saloons were open for business in the cities, especially along the Mississippi River. In smaller communities drug stores supplied alcohol for almost any medicinal purpose. David Brant later wrote:

Even at the [1889] republican convention time the Savery Hotel drug store had lines of men going through the form of signing certificates that the whiskey being bought was for medicinal purposes. Bell boys would go out and bring in beer and whiskey for any guests who ordered the beverages. In the county and district headquarters was to be found, in most cases, bathtubs stocked with ice and beer, and the night before the party declared for no backward step on liquor legislation and that prohibition had become the settled policy of the state, many delegates and officials were up till the small hours treating and drinking at hotel headquarters. With such exhibitions of hypocrisy it is little wonder that defeat was in store for the party. ${ }^{15}$

${ }^{13}$ Washington Gazette, 11 August 1893 (hereafter cited as Gazette).

${ }^{14}$ Dan Elbert Clark, "The History of Liquor Legislation in Iowa 1878-1908," Iowa Journal of History and Politics 6 (October 1908): 591. For the story of liquor legislation before 1878 see the same author's "The Beginnings of Liquor Legislation in Iowa," Ibid. 5 (April 1907); "The History of Liquor Legislation in Iowa 1846-1861," Ibid. 6 (January 1908); "The History of Liquor Legislation in Iowa 1861-1878," Ibid. 6 (July 1908).

${ }^{15}$ David Brant, "David Brant's Iowa Political Sketches," Iowa Journal of History 53 (October 1955): 362. 


\section{Prohibition Debate}

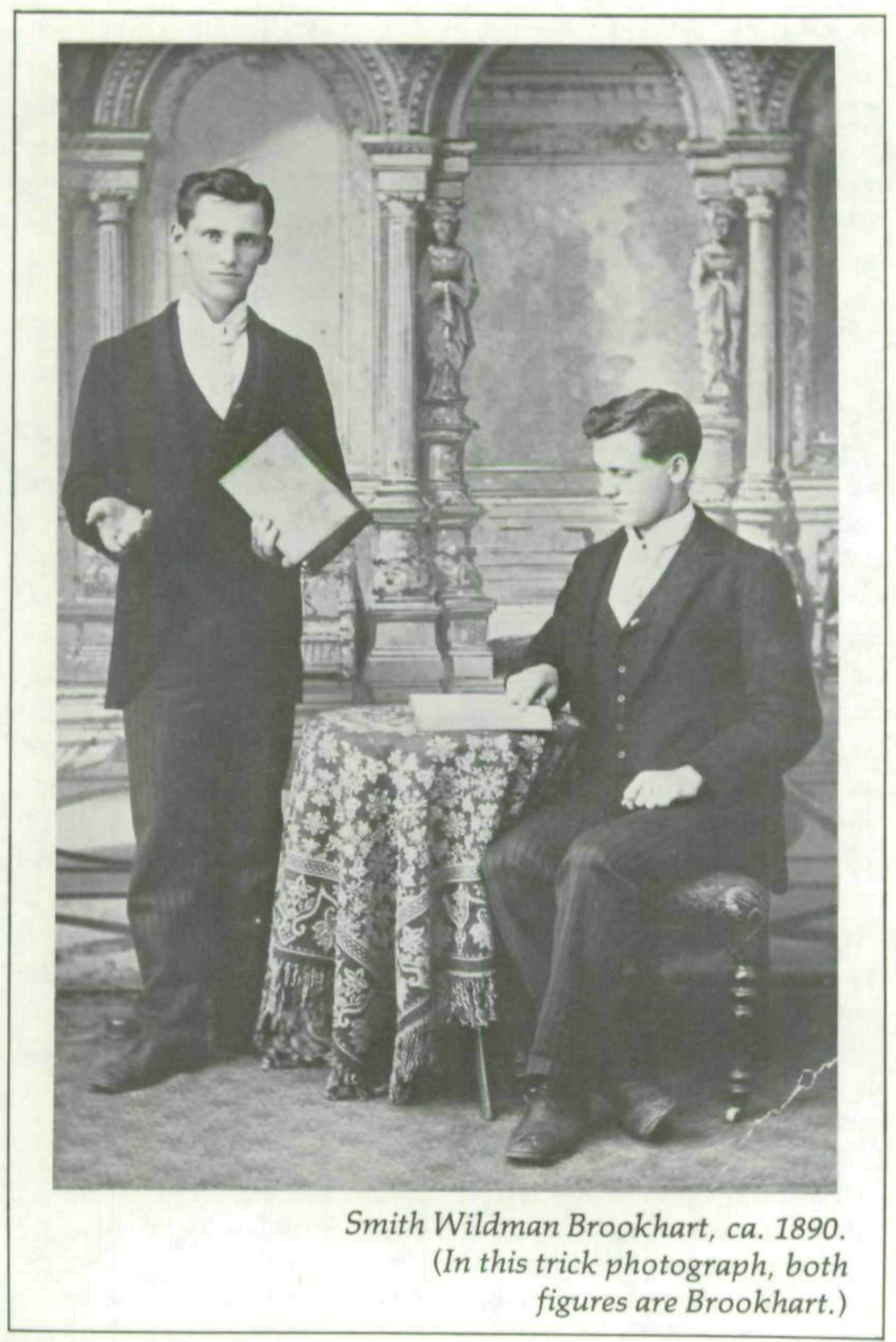

The problem, then, was how to reorient the party away from the rigid and unrealistic dry position and thus win back the wandering moderates and with them the statehouse.

The central committee implemented its conciliation plan 
when Brookhart and other delegates met at the state convention in late August 1893. The first part of the plan had a stroke of genius about it: the committee persuaded James Harlan to be temporary chairman of the convention and to make the keynote address. Harlan was one of the founders of the Republican party. He served as United States senator from 1855 to 1873 . An early supporter of Abraham Lincoln, Harlan was briefly a member of Andrew Johnson's cabinet. In 1882 he had supported the prohibition amendment but when it was ruled null, he took the position that the same result could be achieved by legislation.

Harlan began his speech by listing his credentials as a Republican. He then asked the convention, " . . . if I do not know what Republicanism and its legitimate fruits are, who does?" He maintained that the recent defeats had nothing to do with the basic principles of Republicanism. Rather, the defeats came about, Harlan said, because recent Republican platforms had included "specific statutes or proposed statutes, instead of principles, on which statutes should be founded." The only obstacle, he continued, "to our rightful triumphs from year to year has been of our own creation; merely inharmony among ourselves arising over the discussion in our political campaigns of questions lying outside of the legitimate purview of the principles of the party to which we belong." 16

Harlan's speech was greeted with a "tremendous storm of applause" by the assembled Republicans. The central committee then moved to build on the good feeling: they introduced a prohibition plank that at once broke the Republican-prohibition tie and put the question on the floor of the legislature. The plank, number thirteen in the platform, read in full:

That prohibition is no test of Republicanism. The General Assembly has given to the State a prohibitory law as strong as any that has ever been enacted by any country. Like any other criminal statute, its retention, modification or repeal must be determined by the General Assembly, elected by and in sympathy with the people, and to it is relegated the subject, to

${ }^{16}$ Johnson Brigham, James Harlan (Iowa City: State Historical Society of Iowa, 1913), pp. 300-304. 


\section{Prohibition Debate}

take such action as they may deem just and best in the matter, maintaining the present law in those portions of the State where it is now or can be made efficient, and giving to other localities such methods of controlling and regulating the liquor traffic as will best serve the cause of temperance and morality. ${ }^{17}$

The central committee hoped this plank would mollify both factions of the party. They were wrong. At the convention Judge George B. Struble of Tama County moved to strike out everything beginning with the word "maintaining." $\mathrm{He}$, and the prohibitionists who supported his motion to amend, said the plank as it stood "instructed the General Assembly for local option." The anti-prohibitionists, however, preferred the plank as it was, because they felt local option would give relief to those counties "where prohibition was a burden and a failure." The debate lasted three hours and at the end of it the Struble amendment lost, 613 to $590 .^{18}$ The Washington Press (August $23,1893)$ reported that the local delegation voted twelve yes and two no. Although the Press did not name the delegates, it seems likely, in the light of later events, that Charles J. Wilson, whom Brookhart would later defeat for county attorney, was one of the two voting against the prohibitionists' amendment.

\section{$T_{1}$}

HE FIGHT over the Struble amendment brought into the open the rift between Republicans in Washington County. The two Republican newspapers, the Gazette and the Press, had begun to draw the lines on the prohibition question in 1890. In December of that year D. H. Logan of the Gazette commented that the arrest and conviction of some saloon keepers in Keokuk would be a good thing. Logan continued, " . . . it is about time lawabiding citizens had an opportunity to manage affairs for a time." ${ }^{19}$ The next month Logan noted the trend by some Republicans to abandon the war on saloons, a course he felt was "foolish and suicidal." The issue, he said, is "the home versus the saloon." And he called local option the first retreat by which

${ }^{17}$ Iowa Official Register, 1894 (Des Moines: Geo. H. Ragsdale, state printer, 1894), p. 100.

${ }^{18}$ Clark, "History of Liquor Legislation 1878-1908," p. 592.

${ }^{19}$ Gazette, 26 December 1890. 
the final battle is lost. ${ }^{20}$ On the other hand, Howard A. Burrell, editor of the Press, stated, "Speaking for ourself alone, and not for the Republican party, we are free to say that in our judgment local option is precisely what Iowa needs." ${ }^{21}$

The editors quickly stated their views after the convention. Logan and Neal commented first: "It is hardly necessary to say the [prohibition plank] is not the plank which the Gazette favored." They did feel, however, that if good Republicans were elected to the general assembly they could be "safely trusted" with the issue. The next week Burrell said he thought the prohibition plank as it stood was "a sensible, manly thing to do." It was "a sign of sanity returning; a symptom of getting back from 10 years' bootless wild goose chase after sentimental theories, with a determination, first and foremost, to be Republicans, and not ideologists." While Washington County was an "oasis ... where the law has been, and is well enforced ..." in many parts of the state prohibition plainly was not working and the law was ignored. "It was wise," Burrell concluded, "to defeat the Struble amendment." 22

The editors continued their battle of words into October. On the thirteenth Logan and Neal cautioned prohibitionists against wasting their vote by scratching for Bennett M. Mitchell, the Prohibition party candidate for governor. Mitchell had no chance of winning, and "if we do not hold what ground we have got the thing will be swept from the statutes entirely." Burrell reiterated his position that support of the prohibition plank reinforced the status quo. Iowa had no statewide prohibition and it asked others to "please stop this nonsense of assuming that we have, and have had [it], for we have not had it." He continued, "Also stop the nonsense of saying we mean to bring saloons back, whereas they never went away out of many sections. Dry land is to be left dry land; beer-wet land is to be drained-in the way of taxes and heavy mulct as additional penalties." 23

In the meantime county chairman Brookhart was busy with a speaking tour throughout the county. Between October 18 and

${ }^{20}$ Gazette, 16 January 1891; Ibid., 10 April 1891.

${ }^{21}$ Press, 1 July 1891.

${ }^{22}$ Gazette, 18 August 1893; Press, 23 August 1893.

${ }^{23}$ Gazette, 13 October 1893; Press, 18 October 1893. 


\section{Prohibition Debate}

November 4 he spoke in seven of the fifteen townships in the county. At various times on this speaking tour he appeared with Colonel William B. Bell, D. H. Logan, Jackson Roberts, and W. R. McClean. At Highland Township on the eighteenth the Press reported, "Brookhart made a forcible discussion of the national issues and took first rate." McClean "paid his respects to the unco gude [sic] prohibitionists, who have too much conscience to give full vote to Jackson, but just enough conscience to give, each, half a vote to Boies." Between them the correspondent notes, they left "Old Highland ... so hot she sizzles." 24

It remained, however, for Logan and Neal to have the last word. In a terse editorial in the Gazette (November 4, 1893), they picked up the gauntlet they felt had been thrown at the feet of the prohibitionists:

The thirteenth plank of the Republican platform has proved to be a pretty good temperance plank after all. It has made wideawake prohibitionists out of a number of men who never had any time for politics before. They have learned that a man does not do his whole political duty by simply going to the polls and voting. They have learned that it is their duty to attend primaries, caucuses and conventions and that they ought to help get out the vote on election day. That thirteenth plank has shown some men their faults and shortcomings as they never saw them before and for that reason the Gazette can regard it with a good deal of complacency. ${ }^{25}$

The newly awakened dry Republicans in Washington County were no doubt further spurred by Governor Frank D. Jackson's inaugural address. While he affirmed that the prohibition principle was satisfactory in many locations, he felt that "wisdom, justice, and the interests of temperance and morality demand that a modification of this law should be made." Such modification ought to apply to those communities where the saloons existed, "to the end of reducing the evils of liquor traffic to the minimum." 26

${ }^{24}$ Press, 18 October 1893; Ibid., 25 October 1893.

${ }^{25}$ Gazette, 4 November 1893.

${ }^{26}$ Benjamin F. Shambaugh, ed., The Messages and Proclamations of the Governors of Iowa (Iowa City: State Historical Society of Iowa, 1905), 7:16. 
A number of liquor bills were introduced into the legislature in 1894, but the one which caused the most comment and seemed most likely to meet the governor's criterion of modification was the mulct law. Based on a similar law in Ohio, the mulct law provided that a tax of six hundred dollars be levied against anyone other than a registered pharmacist who sold liquor. Upon payment of the tax they could continue to sell liquor and not be subject to prosecution. The mulct was in no way construed as a legalization of liquor, thus satisfying the drys; at the same time it allowed local option sales of liquor, the goal of the wet moderates. In cities of five thousand or more inhabitants, the law could become operative only upon signed agreement of a majority of the voters in the previous election. In smaller communities (such as Washington) 65 percent of the voters in the county had to agree to it. The practical result of the mulct law was that the local government, by virtue of the payment of a tax, allowed the law to be broken.

No sooner had the debate begun in the legislature than it was taken up in Washington County. The Washington Press was already on record. In April of the previous year it called the mulct law in Ohio "mere thimblerig . . . and boy's play." ${ }^{27}$ Nonetheless, in January 1894 Burrell supported the bill. James Dawson, one of the founders of the city and a dry, protested in a letter to the editor that the Republican party ought to stand firm on its record of temperance-to go back on that record by any modification of the law "would be an outrage." Burrell responded that the mulct would allow adjustment to local circumstances and therefore the mulct "would not affect [Washington] county a bit." This is consistent with Burrell's longstanding position in favor of local option. Then, sounding a familiar moderate theme Burrell continued:

Let's be practical, and not sentimental. . . We are on earth . . . we are not in heaven, or living where perfect social conditions can be manufactured and maintained. It would be foolish to legislate as angels and for angels, when there isn't an angel in all of Iowa. ${ }^{28}$

${ }^{27}$ Press, 26 April 1893.

${ }^{28}$ Press, 31 January 1894. 


\section{Prohibition Debate}

Predictably, Logan and Neal of the Gazette were opposed to the mulct law. While admitting they would have preferred "straight prohibition," the editors realized that "a great many good people thought the law ought to be modified." If the mulct does not work, however, " . . . we give fair warning that a constitutional amendment will be passed by a majority that will be respected. We cannot always have our own way and are willing to try this law and shall be pleased if it does all that has been promised by its friends." 29

The drys clearly saw the mulct as another form of local option. There had been saloons in Washington city and county, and at one time as many as three breweries. "For years," according to one historian of prohibition, S. N. Fellows, Washington experienced "saloon fights, drunken fathers, brothers and sons [which] made nights hideous; heavy taxes, full jail and poorhouse were the order of the day." However, enforcement of the prohibition laws of 1883 and 1885 had its effect and by 1887 a poll commissioned by Governor William Larrabee showed no saloons in Washington County. By 1889, Fellows continued, "it was declared that there were no saloon fights, seldom a drunken man on the streets, happy homes, well-fed and clothed women, with peace and quiet day and night." Drys wanted "peace and quiet day and night" to remain a characteristic of Washington County. To insure that it would continue to be so the drys moved to make sure the enforcement officer of the law was a dry. And in section fifteen of the mulct law, enforcement of the law was given to the county attorney. ${ }^{30}$

The incumbent Washington County attorney, Charles James Wilson, announced in $\mathbf{1 8 9 4}$ he would not be a candidate for reelection. There were two announced candidates for the Republican nomination: A. S. Folger, a local attorney and insurance man, and Smith W. Brookhart. Logan and Neal wrote in the Gazette (August 3, 1894) that Folger was "an old soldier, a good

\section{${ }^{29}$ Gazette, 30 March 1894.}

${ }^{30}$ Kathy Fisher, In the Beginning There was Land: A History of Washington County, Iowa (Washington: Washington County Historical Society, 1978), pp. 313-323; S. N. Fellows, History of Prohibition in Iowa (Des Moines: Iowa Anti-Saloon League, 1905), p. 11; Clark, "History of Liquor Legislation 1878-1908," pp. 560, 568; Press, 18 April 1894. 
The Annals of Iowa

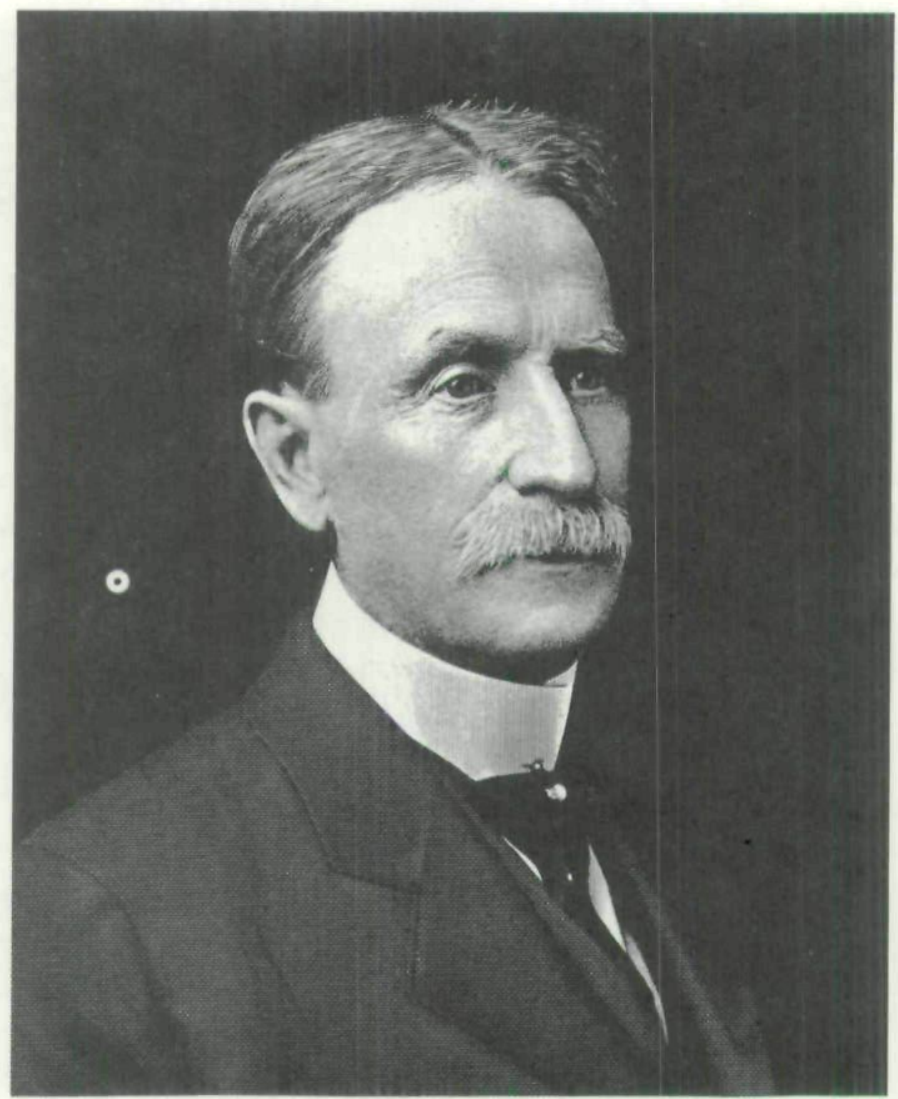

Howard A. Burrell, editor of the Washington Press.

honest man" but that Brookhart, "a very bright young attorney," would be "a good stumper and would add strength to the ticket." Burrell noted that both were reputable men but that since Folger had been a county attorney in Indiana he was "familiar with the work." Brookhart, Burrell continued, "is a young man of reading, industry and considerable experience." ${ }^{31}$

In fact, Burrell and the moderates had another candidate in mind. Eighteen years later a Press editorial commented upon the effort to keep Brookhart from being county attorney in

${ }^{31}$ Gazette, 3 August 1894; Press, 15 August 1894. 


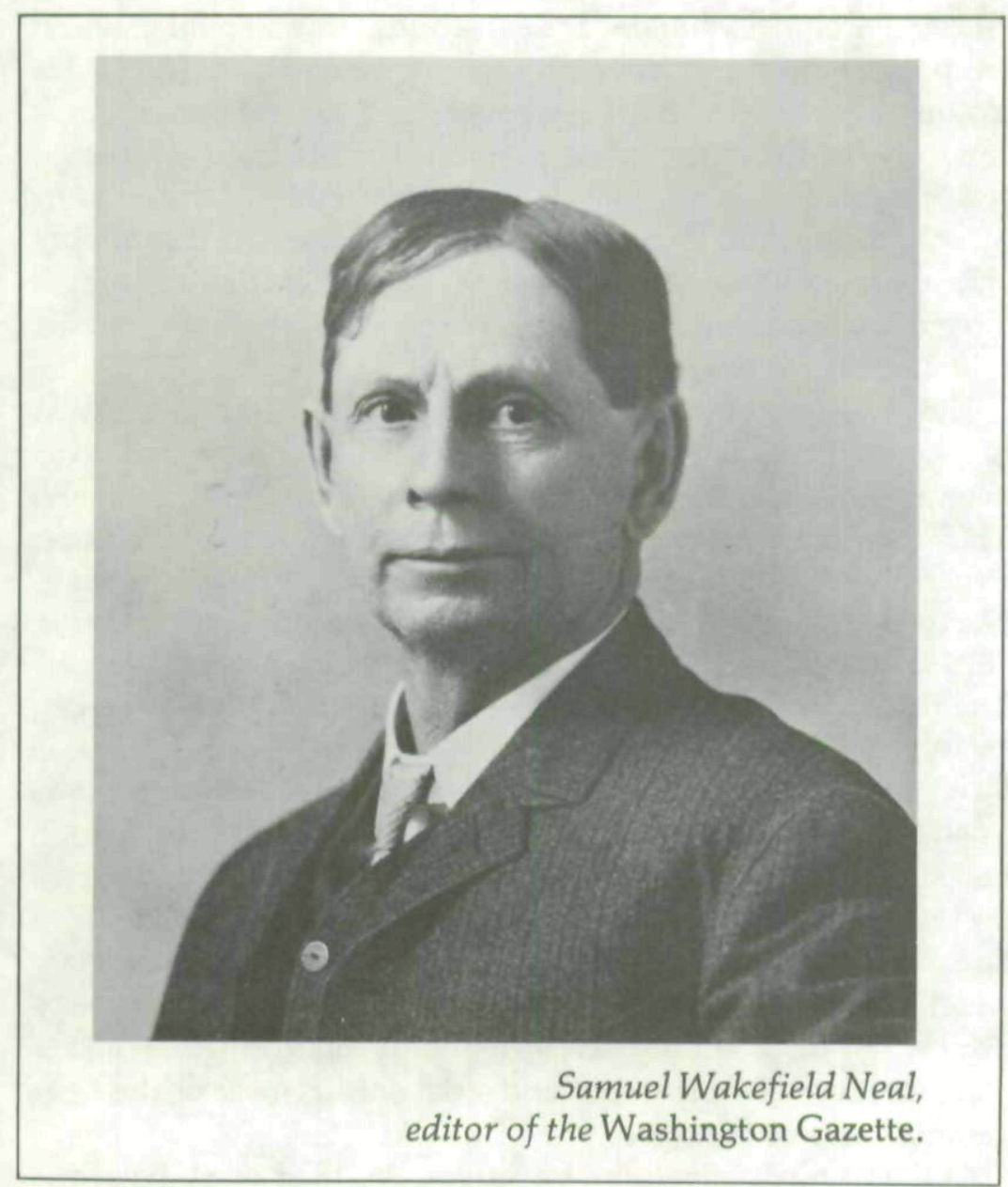

1894. "Even in those early days Burrell had cooked up the cutest little deal to beat Brookhart and nominate another man for a fifth term. . . . "32 Apparently, the "cute little deal" was to have Wilson declare his non-candidacy and then have the county convention draft him. But Burrell and Wilson did not control the convention as well as they thought.

The drys had been busy organizing. Brookhart later listed those "republicans that made [him] county attorney" in 1894: D. H. Logan and Wake Neal, editors and publishers of the

${ }^{32}$ Press, 12 December 1912; Ibid., 2 January 1913. In 1911 Brookhart and three others bought the Press; the editor and manager was $\mathrm{H}$. H. Walter. 
Gazette; Colonel William B. Bell, a long-time Republican and temperance man and currently state representative; John Alex Young, a banker who had been county auditor and mayor; Jackson Roberts, Brookhart's law partner; Vint Nash, Sam Thompson, Joseph H. Huston, Eusebius W. H. Ashby, farmers; Dr. Joseph Sheafe; and Benjamin F. Brown, farmer, Anti-Monoply state representative, and member of the Farmers and Laborers', Greenback, and Populist parties. There were others, Brookhart said, "but these were the leaders." 33

They were the older generation. In 1894 their average age was fifty-four; Brookhart was twenty-five. Six were Civil War veterans. They were professional men and successful farmers. They were all long-time Republicans: Young had won his first election when Brookhart was two years old; Roberts, Young, Huston, and Neal were delegates to the county convention in 1879; and Bell went to the congressional convention that year. The position of some of these men on the prohibition issue can be inferred. Logan and Neal were responsible for the Gazette's strict dry editorial policy; furthermore, Neal was for many years the superintendent of the Methodist Sabbath School. Bell's association with prohibition went back at least as far as the 1874 formation of the Washington County Temperance Society. As state representative he voted against the mulct law which he understood to be a form of license. And in 1874 Brown ran on a county Anti-Monopoly platform that had a plank in favor of temperance and strict enforcement of the temperance laws of the state. ${ }^{34}$

At the county convention on August 25, their work paid off. Brookhart was named the party's candidate for county attorney on the second ballot with sixty-one votes. Wilson was second with thirty, and Folger received thirteen. After praising Brookhart's victory, the Gazette's editors succinctly added: "C. J.

${ }^{33}$ Press, 2 January 1913; biographical information from various sources including: Howard A. Burrell, History of Washington County, Iowa, From the First White Settlements to 1908, 2 vols. (Chicago: S. J. Clarke Publishing Company, 1909); Portrait and Biographical Album of Washington County, Iowa (Chicago: Acme Publishing Company, 1887). There is no biographical information on D. H. Logan or Dr. Sheafe.

${ }^{34}$ Press, 11 June 1879; Gazette, 30 March 1894; Iowa State Register, 24 June 1874. 


\section{Prohibition Debate}

Wilson also made a good run although not a candidate." Whatever differences Washington County Republicans may have had, the two camps soon closed ranks, at least publicly. On October 31 the Press endorsed Brookhart: "[He] has the stuff and work in him . . . and we confidently bank on him." Brookhart won the election with 57.6 percent of the vote. ${ }^{35}$

After this initial skirmish between the drys and moderates in Washington County their differences seemed to fall into the background. In part this can be attributed to the mulct law. While not an overwhelming statewide success, at least according to the drys, it did work where people wanted it to. Governor Jackson reported that by July 1, 1895, fifty-one counties, including Washington County, had not adopted the mulct law and therefore were still operating under the prohibition laws. By 1900 the state auditor noted in his biennial report that in the year ended July 1,1899 , fifty-one counties still had not adopted the mulct law. And in 1909 one writer noted that although the mulct law is "as illogical a law . . . as can be found anywhere," still it came to be accepted as "the final solution of the liquor problem in the State." ${ }^{36}$

As the mulct law tended to quiet debate on the liquor issue, other issues came to the foreground. The problem of the railroads and the political control they exercised in Iowa, and the silver monetary question focused attention away from the saloon. Meanwhile, Smith Brookhart settled into his life as county attorney. He was renominated by acclamation for a second term in 1896 and after enthusiastic endorsements by the Press and the Gazette he was reelected. When war came in 1898 Brookhart, a member of the National Guard, was called up for active duty and so he resigned as county attorney. Returning from the war in the autumn Brookhart was selected as the nominee for both the remainder of the term from which he had

${ }^{35}$ Press, 29 August 1894 (Two others also received votes at the county convention-a Mr. Meacham got 13, Mrs. Meacham got 1.); Gazette, 31 August 1894; Press, 31 October 1894; Ibid., 14 November 1894.

${ }^{36}$ Shambaugh, Messages and Proclamations, 7:50; "Biennial Report of the Auditor of State," Iowa Documents, 1900, 7 vols. (Des Moines: F. R. Conaway, state printer, 1900), 1:194; William R. Boyd, "Liquor and Common Sense in Iowa," Harper's Weekly 53 (19 June 1909): 13. 
resigned and the full term beginning in 1899 . He was handily elected to both terms. ${ }^{37}$

Smith Brookhart and the dry Republicans were crusaders. They regarded liquor as an attack on home and family which needed to be vigorously fought. To them it was an issue which transcended all others and thus they were unwilling to compromise. In Brookhart's initial election campaign he assumed a status quo position within the Republican party by fighting those Republicans with more moderate viewpoints. Within a few years Brookhart would be again fighting the same Republicans in Washington County-ironically, however, as a Cummins Progressive. By then he had cast off the cloak of status quo.

Brookhart began his political career by taking the unpopular side of the liquor question. With that, a mold was set and he would find himself on the unpopular side of the political spectrum for most of his career. In 1910 he ran for first district congressman and lost. Soon after the election he wrote Senator Jonathan P. Dolliver to say he was not discouraged. "I have already . . ground my battle ax for the next encounter." And then, in what most certainly was an echo of the dry Republicans in the 1890 s, Brookhart added, "I would rather be right than regular any day." ${ }^{38}$

${ }^{37}$ Press, 27 May 1896; Ibid., 26 August 1896; Ibid., 18 November 1896; Gazette, 30 October 1896.

${ }^{38}$ Brookhart to Dolliver, 16 June 1910, Box 56, Folder 7, Jonathan P. Dolliver Papers, Manuscript Collection, Division of the State Historical Society, Iowa State Department of History, Iowa City, Iowa. 
Copyright of Annals of Iowa is the property of State of Iowa, by \& through the State Historical Society of Iowa and its content may not be copied or emailed to multiple sites or posted to a listserv without the copyright holder's express written permission. However, users may print, download, or email articles for individual use. 